\title{
On the distribution of the deepwater ostracode Archiconchoecilla maculata (Chavtur, 1977) (Crustacea: Ostracoda: Myodocopa: Halocyprida: Archiconchoecinae)
}

\author{
J.A. Rudjakov
}

Department of Invertebrate Zoology, Museum of Comparative Zoology, Harvard University, 26 Oxford Street, Cambridge, Massachusetts 02138-2902, U.S.A.

E-mail: rudyakov@fas.harvard.edu

\begin{abstract}
Based on unpublished data, the planktonic halocyprid ostracode Archiconchoecilla maculata (Chavtur, 1977) has a much wider geographical and depth range than noted by Chavtur (1977) and Chavtur and Stovbun (2003), based on the specimens collected by RV Vityaz in the Kurile-Kamchatka Trench between 7000-8700 m depth. According to an unpublished manuscript by Rudjakov (1960) this species was found in three samples collected by RV Vityaz in the Bougainville and Mariana Trenches between 2000-8000 m depth. Judging by its depth distribution, the species should be placed into deep-water nearbottom fauna. However, some individuals can ascend to much shallower depths and allow genetic material exchange among populations inhabiting separate deep-water trenches. How to cite this article: Rudjakov J.A. 2014. On the distribution of the deepwater ostracode Archiconchoecilla maculata (Chavtur, 1977) (Crustacea: Ostracoda: Myodocopa: Halocyprida: Archiconchoecinae)// Invert. Zool. Vol.11. No.2. P.347-352.
\end{abstract}

KEY WORDS: Ostracoda, Myodocopa, Halocyprida, Archiconchoecia, Archiconchoecilla, deep-sea fauna, near-bottom, Pacific.

\section{О распределении глубоководной остракоды Archiconchoecilla maculata (Chavtur, 1977) (Crustacea: Ostracoda: Myodocopa: Halocyprida: Archiconchoecinae)}

\section{Ю.А. Рудяков}

Department of Invertebrate Zoology, Museum of Comparative Zoology, Harvard University, 26 Oxford Street, Cambridge, Massachusetts 02138-2902, U.S.A.

E-mail: rudyakov@fas.harvard.edu

РЕЗЮМЕ: Планктонная остракода Archiconchoecilla maculata (Chavtur, 1977) из отряда Halocyprida имеет более широкое горизонтальное и вертикальное распределение чем можно было предполагать на основании данных, приведенных в первоначальном (Чавтур, 1977) и дополнительном (Чавтур, Стовбун, 2003) описаниях этого вида. Оба описания были основаны на экземплярах, собранных НИС Витязь в Курило-Камчатской впадине в слое 7000-8700 м. В соответствии с моей неопубликованной рукописью (Рудяков, 1960), этот вид был обнаружен в пробах, полученных экспедициями на НИС Витязь во впадинах Марианской и Бугенвиль в диапазоне глубин от 2000 до 8000 м. Судя по вертикальному распределению особей этого вида, его следует отнести к тем представителям глубоководной придонной фауны, отдель- 
ные особи которых могут подниматься на значительно меньшие глубины и обеспечивать обмен генетическим материалом между популяциями отдельных океанических впадин.

Как цитировать эту статью: Rudjakov J.A. 2014. On the distribution of the deepwater ostracode Archiconchoecilla maculata (Chavtur, 1977) (Crustacea: Ostracoda: Myodocopa: Halocyprida: Archiconchoecinae) // Invert. Zool. Vol.11. No.2. P.347-352.

КЛЮЧЕВЫЕ СЛОВА: Ostracoda, Myodocopa, Halocyprida, Archiconchoecia, Archiconchoecilla, глубоководная фауна, придонные организмы, Тихий океан.

\section{Introduction}

Chavtur (1977) described the ultra-abyssal species of Archiconchoecinae - Archiconchoecia maculata Chavtur, 1977 that was included in the new genus Archiconchoecilla and redescribed in greater detail by Chavtur and Stovbun (2003). The species (23 males, 26 females and 13 juveniles) was found in a sample taken by RV Vityaz in the Kurile-Kamchatka Trench area at station $5626\left(45^{\circ} 11^{\prime} \mathrm{N}, 152^{\circ} 28^{\prime}\right.$ E) in a layer $9,500-7,280 \mathrm{~m}$ of wire out that Vinogradov (1968) equated with 8,700-7,000 m depth. The station was observed on 24.08.1966.

The unique form of the shell and some other morphological peculiarities of the species left no doubt in conspecificity of $A$. maculata with an unpublished name "A. abyssalis" the description of which I included in my Master of Science thesis (Rudjakov, 1960). The thesis was deposited in the Ernst Mayr Library of Harvard University's Museum of Comparative Zoology on 5.02.2003. Previously it was kept at the Department of Invertebrate Zoology of the Biological Faculty of the M.V. Lomonosov State University in Moscow and was not readily available to the public. Some parts of the manuscript were published later (Rudjakov, 1962) and some data and conclusions were cited and used in oceanographic literature (Vinogradov, 1968; Rudjakov, 1986). Unfortunately, the specimens mentioned in the manuscript were destroyed by a flood in the storeroom of the P.P. Shirshov Institute of Oceanology in Moscow and cannot be reexamined.

Since the manuscript does not constitute a published work (ICZN, 1999) the names of new species described in it have no taxonomic status. However, taxonomic observations and additional data on geographical and depth ranges of A. maculata call for publication.

\section{Results}

The specimens of $A$. maculata described by Rudjakov (1960) were collected at two RV Vityaz stations with a Bogorov-Rass' vertical closing net BR 113/140 (the mouth area $1.0 \mathrm{~m}^{2}$ ). Real fishing depths (in parentheses) are given according to Vinogradov (1968):

Bougainville Trench: St. 3663.26.07-27.07. $1957,6^{\circ} 17^{\prime} \mathrm{S}, 153^{\circ} 45^{\prime} \mathrm{E}, 8,200-6,700 \mathrm{~m}$ of wire out $(\sim 8,000-6,000 \mathrm{~m}$ depth $)-14$ males, 18 females, 3 juv; Mariana Trench: St. 3686. 13.08. $-15.08 .1957,13^{\circ} 53^{\prime} \mathrm{N}, 147^{\circ} 01^{\prime} \mathrm{E}, 4,400$ $2,500 \mathrm{~m}$ of wire out $(\sim 4,000-2,000 \mathrm{~m}$ depth $)$ 1 female), $8,000-4,400$ m of wire out $(\sim 8,000$ $4,000 \mathrm{~m}$ depth $)-3$ specimens, gender undetermined.

The morphological characters of specimens from Rudjakov (1960) are depicted herein in Fig. 1 and their description translated from Russian is given below.

Male. The shell (Fig. 1A-C) is delicate, transparent, with the eye-catching asymmetry of left and right valves. The right valve has a deep notch in the dorso-posterior area. The posterior margin of the right valve gradually transforms into the ventral margin with no noticeable corner between the two. The left valve has no notch in the dorso-posterior area. Its dorsal and ventral margins are approximately parallel and build, with the posterior margin, clearly discernible but significantly rounded 

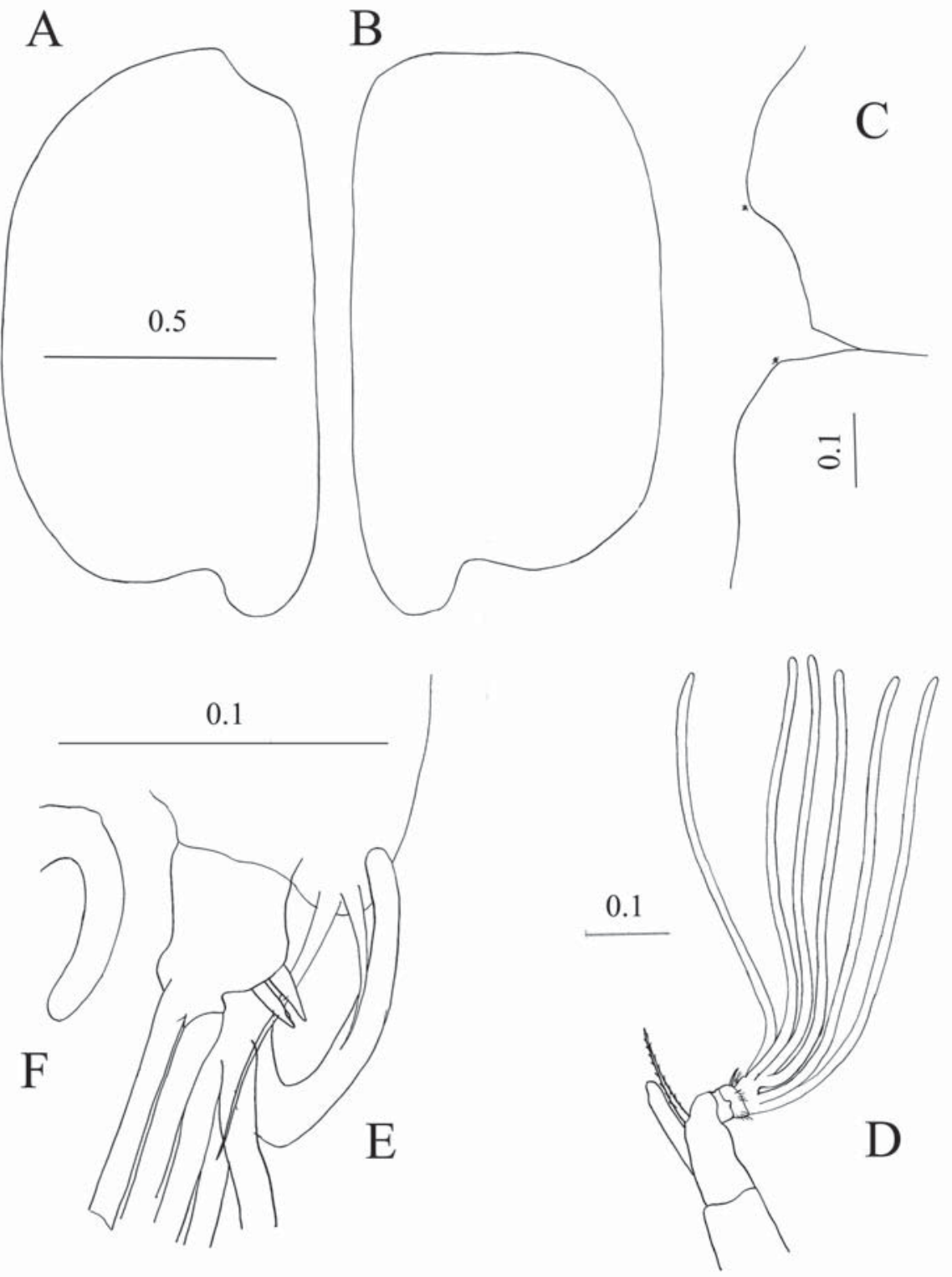

Fig. 1. Archiconchoecilla maculata (Chavtur, 1977) (from Rudjakov, 1960).

A-B - right and left valves of male, correspondingly, outside view; C - posterior part of both valves of female, inside view, location of asymmetrical glands is indicated with asterisks; D - right first antenna and frontal organ of male; E$\mathrm{F}$ - endopod of right second antenna of male and left clasping organ, correspondingly.

Рис. 1. Archiconchoecilla maculata (Chavtur, 1977) (из Rudjakov, 1960).

A-B - правая и левая створки раковины самца, соответственно, вид снаружи; С - задняя часть створок раковины самки, вид изнутри, положение асимметричных желез указано звездочками; D - правая первая антенна и фронтальный орган самца; E-F - эндоподит правой второй антенны самца и левый крючковидный орган, соответственно. 
corners. Length of male $1.10-1.25 \mathrm{~mm}(1.16$ $\mathrm{mm}$ as an average).

Incisure and rostrum are small.

The left asymmetric gland is located on the dorso-posterior corner of the left valve and the right gland - in the corner between the posterior margin of the right valve and the margin of the notch.

The length of frontal organ exceeds the combined length of the two first articles of the first antenna. Its tip is rounded.

First antenna (Fig. 1D). The dorsal seta of the second article is furnished with shortslender spines; its length is equal to the length of the article. Terminal articles bear groups of small hairs.

Endopod of the right second antenna (Fig. 1E). Processus mamillaris is absent. First article is partly covered with small hairs and bear two fairly long setae, the distal of which is noticeably longer than the other. The clasping organ is well developed. It is bent with acute angle at the first third of its length and bears a conspicuous tubercle at its base. By its base, two large blunt teeth are located. The clasping organ of the left second antenna (Fig. 1F) is shorter and not so sharply bent. It has a barely noticeable tubercle at the bend. Furcal lamellae are armed with 8 claws each.

Female. The length 1.13-1.23 mm (average $1.18 \mathrm{~mm}$ ). The shell of female has a lower ratio of height to length $(13 / 37=0.35)$ than that of male $(14 / 25=0.56)$.

\section{Discussion}

My unpublished description (Rudakov, 1960) shows no substantial differences from those by Chavtur $(1977,2003)$.

Indeed, height to length ratios in my description may seem different from those given by Chavtur. He indicated the value of $52-53 \%$ for females in the paper published in 1977 but for males in the revised description of 2003. Unfortunately, he provided no information on the ratio for the shells of the opposite gender, i.e. for males in the paper of 1977 and for females in the paper of 2003. Therefore, it is not absolutely clear whether his specimens show evidence of sexual dimorphism in relation to this character. As mentioned in the description above, the shell is extremely delicate. Because of this, the measurements should be taken using intact specimens placed in a container with sufficient amount of liquid. I cannot guarantee that all of my measurements met the requirements and therefore the extremely low height to length ratio for females given in my description seems doubtful.

The second difference pertains to the dark pigment granules ("chromatophores" or "pigment spots" as they were described by Chavtur in his papers of 1977 and 2003, correspondingly) located within articles of the first and second antennae. Chavtur evidently was inclined to give them some taxonomic importance since their presence served as a basis for the selection of the species name "maculata" or "spotted". The granules were not been mentioned in my description of 1960 , possibly due to the fact that I observed similar pigment granules in some other halocyprids and did not consider their presence as a taxonomically important character. The granules have been described for different halocyprid genera and can be seen in drawings that Chavtur provided for some other genera and species. Sars $(1922$, p. 23$)$ in his description of Conchoecia elegans pointed out that "Anterior antennae... exhibiting within their proximal part a number of dark yellow corpuscles, also found in other species, and apparently visual in nature". A possible function of those granules was discussed by Skogsberg (1920). There is a possibility that the granules can fade out and even become invisible due to fixation and subsequent storage.

One more difference can be seen in the shape of the thin-walled sensory bristles of the first antennae. Their tips are shown tapered in figures by Chavtur but round in my figures. However, the figures given by different authors in published literature and their comparison with the morphology of halocyprid species from the collection of the Museum of Comparative Zoology demonstrate that the tips of the sensory bristles are extremely fragile and can hardly be of any taxonomical importance. 
Judging from the data at hand, A. maculata has a wide range of depth distribution extending over a few thousand meters. However, only one specimen was caught between 4,000 and $2,000 \mathrm{~m}$ depth. The other 100 specimens were taken from greater depths with 62 specimens taken between 8,700 and 7,000 $\mathrm{m}$ depth and 35 specimens collected between 8,000 and 6,000 $\mathrm{m}$ depth. The species certainly demonstrates its adherence to deeper layers of its depth range. This type of vertical distribution is not known among the majority of pelagic species that utilize food resources of photosynthetic near-surface layer and population density of which decreases with the distance from the surface, i.e. with increasing depth. Using the same way of thinking, for planktonic species exploiting food resources of the water layer adjacent to the bottom, we can expect a decrease of population density with increasing distance from the bottom. In contrast to the much better known near-surface species, deepwater planktonic species with this type of vertical distribution should be placed into the near-bottom fauna.

Finding $A$. maculata in the trenches so greatly distant from each other allows concluding that the species distribution cannot be cited as an example of "ultra-abyssal endemism", a concept developed by Zenkevich, Birstein and Belyaev (Zenkevich et al., 1955; Birstein, 1963) on the basis of investigation of benthic deepwater samples collected by RV "Vityaz". Judging by the available data, some specimens of $A$. maculata actively ascend or get transported by water movements well above the thresholds separating individual trenches. Those expatriates can ensure interbreeding and gene exchange between the populations inhabiting separate trenches and bring to nil a possibility of endemism occurrence.

\section{Acknowledgments}

Professor Ya.A. Birstein granted me his friendly guidance and invaluable assistance during the taxonomic treatment of samples, in pondering possible ecological inferences and in the composing of the manuscript which became the basis for this paper. Professor L.A. Zenkevitch scrupulously reviewed the manuscript and offered invaluable constructive criticism. Although both passed away many years ago, I have never ceased to experience the feeling of deepest gratitude to these great men, charismatic teachers and distinguished scientists and I am happy to have been one of their students and successors. This paper could not have been completed without the help of Dr. Gonzalo Giribet and Adam Baldinger who provided me with the best possible study area and laboratory facilities. Mr. Karsten Hartel generously took over the difficult task of carrying out the first critical reading of the manuscript. The paper greatly benefited from the suggestions offered by Dr. Van Wallach (the last four from the Museum of Comparative Zoology, Harvard University, Cambridge, MA).

\section{References}

Birstein Ya.A. 1963. [Deep water isopods (Crustacea. Isopoda) of the north-western part of the Pacific Ocean]. Moscow: AN SSSR Publ. 213 p. [in Russian, with English summary].

Chavtur V.G. 1977. [Species composition and vertical distribution of pelagic ostracods in the Kurile-Kamchatka Trench region] // Trudy Instituta Okeanologii AN SSSR. Vol.108. P.136-164 [in Russian, with English summary].

Chavtur V.G., Stovbun G.G. 2003. Revision of pelagic ostracods of the subfamily Archiconchoecinae // Publications of the Seto Marine Biological Laboratory. Vol.39. No.4/6. P.139-219.

International Commission on Zoological Nomenclature (ICZN). 1999. International code of zoological nomenclature, $4^{\text {th }}$ Edition. The International Trust for Zoological Nomenclature, London, 306 p. Available at http://www.nhm.ac.uk/hosted-sites/iczn/code/

Rudjakov J.A. 1960. [Ostracoda Myodocopa of the western part of the Pacific Ocean]. Manuscript. Ernst Mayr Library of the Museum of Comparative Zoology. Harvard University. Vol.1-2. 134 p. 149 figs [in Russian].

Rudjakov J.A. 1962. [Ostracoda Myodocopa of the family Halocypridae of the north-western part of the Pacific Ocean] // Trudy Instituta Okeanologii AN SSSR. Vol.58. P.172-201 [in Russian, with English summary].

Rudjakov J.A. 1986. [Dynamics of vertical distribution of pelagic animals]. Moscow: Nauka. 136 p. [in Russian, with English summary]. 
Sars G.O. 1922. An account of the Crustacea of Norway. Vol.9. Parts 1-2. Bergen: Bergen Museum. P.1-32.

Skogsberg T. 1920. Studies on marine ostracods. Part 1. (Cypridinids, Halocyprids and Polycopids) // Zoologiska Bidrag från Uppsala. Supplement Band 1. Uppsala: Almqvist and Wiksells Boktryckeri. 784 p.

Vinogradov M.E. 1968. [Vertical distribution of the oceanic zooplankton]. Moscow: Nauka. 320 p. [in Russian].
Zenkevitch L.A., Birstein J.A, Belyaev G.M. 1955. [Investigation of the bottom fauna of the Kurile-Kamchatka Trench] // Trudy Instituta Okeanologii AN SSSR. Vol.12. P.345-381 [in Russian].

Responsible editors E.N. Temereva, K.G. Mikhailov 